\title{
The impact of Scientific Initiation on the scientific production of graduate students
}

\author{
Tania Adas Saliba*; Lia Borges de Mattos Custódio**; Nemre Adas Saliba***; Suzely Adas Saliba \\ Moimaz $^{* * *}$
}
* Associated Professor, Department of Children and Social Dentistry, São Paulo State University (UNESP), School of Dentistry, Araçatuba
** Graduated student, Public Health Dentistry Program, São Paulo State University (UNESP), School of Dentistry, Araçatuba
*** Full Professor, Department of Children and Social Dentistry São Paulo State University (UNESP), School of Dentistry, Araçatuba

Recebido em 16/05/2019. Aprovado em 23/06/2019.

\begin{abstract}
Scientific Initiation is a Brazilian undergraduate research programme that aims to awaken the scientific vocation of undergraduate students and to encourage potential talents through their participation in research projects under the guidance of a qualified researcher. This study's purpose was to analyse the scientific production of graduate students based on their previous experience with Scientific Initiation. A cross-sectional, descriptive study was conducted by searching databases of Brazilian public agencies - the Sucupira Platform, by the Ministry of Education, and the Lattes Platform, by the Ministry of Science, Technology, Innovation and Communication. We collected studies published between 2012 and 2018 and included all students and newcomers enrolled in master's degree and PhD programmes. We assessed the number of students enrolled in the Public Health Dentistry Graduate Programme of the São Paulo State University (Unesp), School of Dentistry, Araçatuba, Brazil. We analysed the number of scientific papers published by each PhD student and observed that $\mathrm{PhD}$ students who performed Scientific Initiation $(n=19)$ achieved a higher average of scientific production $(\mathrm{p}=0.047)$. In total, 55 master's and $\mathrm{PhD}$ students were enrolled in the Public Health Dentistry Graduate Programme; of these, 63.64 percent $(n=35)$ carried out Scientific Initiation during their undergraduate course. It was concluded that graduate students with Scientific Initiation published more papers than those without this experience.
\end{abstract}

Descriptors: Education, Dental. Education, Dental, Graduate. Dental Research. 


\section{INTRODUCTION}

Formal dental education in Brazil started in 1879 with the introduction of a module on dental surgery, which was assigned to schools of medicine ${ }^{1}$. Since the beginning, the dentistry course curriculum has focused on the curative paradigm, that is, it has not observed the epidemiology or the characteristics of the community in which the university was inserted ${ }^{1}$. This situation lasted for many years. In the end of the 1990s, there was a change in the dental education programme to enable students to perform an academic education on integral basis. This new concept of dental education occurred in several countries ${ }^{2,3}$, including Brazil, where there was the development of new curriculum guidelines with pedagogical planning rules for organization of undergraduate dentistry courses.

In Brazil, new curricular guidelines were introduced. The National Curriculum Guidelines (DCN) for Dentistry Courses ${ }^{4}$ have highlighted the necessity to provide professionals with skills of analysing and assessing the community's problems and needs, including the creation of solutions. They also addressed the role of teachers in the training of undergraduate students by encouraging universities to develop pedagogical projects to stimulate intellectual autonomy, creativity, and formation of critical and reflective professionals ${ }^{5}$. The pedagogical project of dentistry courses should also improve the teaching-learning process by shifting the traditional model paradigm - which was based on transmissive teaching and centred on the figure of the professor - to a model centred on the figure of the student, in which the professor plays the role of intermediating or facilitating the learning process of students ${ }^{6,7}$.

In compliance with the DCNs for Dentistry Courses $^{4}$, the Coordination of Superior Level Staff Improvement (CAPES) of the Ministry of Education included the integration of graduate and undergraduate students as a quality indicator in the evaluation of recommended programmes, thereby contributing to the improvement of undergraduate training and qualification of graduate students for the teaching practice ${ }^{8}$. In this scenario, Scientific Initiation has a fundamental role in integrating undergraduate and graduate students; research and outreach activities enrich the experience of the former, and teaching activities enhance the experience of the latter.

New pedagogical practices are necessary for a transformative education centred on the human condition, on the development of understanding, and on cultural sensitivity and ethics, thus prioritising the construction of transdisciplinary knowledge ${ }^{9}$. Consequently, the university has the role to stimulate, encourage and insert students into research and outreach activities developed in graduate programmes. The insertion of undergraduate and graduate students in the same research or outreach activities raises the quality of academic training for undergraduate students and provides a realistic teaching-learning scenario for graduate students ${ }^{10,11}$. Therefore, this study aimed to analyse the scientific production of graduate students with and without Scientific Initiation.

\section{METHODS}

A cross-sectional, descriptive study was performed based on secondary data available at public agencies' databases: the Sucupira Platform, by the Brazilian Ministry of Education (MEC), and the Lattes Platform, by Brazilian Ministry of Science, Technology, Innovation and Communication (MCTIC). The Sucupira Platform database is a tool for collecting information for analyses and assessments; it is the basis of the National Graduate Programme System (SNPG) ${ }^{8}$. Likewise, the Lattes Platform is an information system that integrates databases of curricula, research groups, and institutions. It represents a national standard record of the past and current academic life of students and researchers in Brazil ${ }^{12}$. The data collection included data from 2012 to 
2018.

There are 4,381 course programmes recognized by CAPES in Brazil. Out of them, 106 are in the Dentistry field. These 106 Dentistry graduate programmes are distributed throughout the five geographic regions of Brazil as follows: the Southeast region has 62 graduate programmes (58.5 percent), followed by the South region, with 19 (17.9 percent), the Northeast region, with 17 (16.0 percent), the Center-West region, with 5 (4.7 percent), and the North region, with 3 (2.8 percent). The sample analysed refers to a graduate programme of the São Paulo area in the Southeast region.

The sample was selected according to student insertion in the Public Health Dentistry Graduate Programme of the São Paulo State University (Unesp), School of Dentistry, Araçatuba, Brazil, recognized by CAPES. We assessed the number of graduate students enrolled in the Public Health Dentistry Graduate Programme and the Scientific Initiation activities developed by these same students during their undergraduate course. We identified the number of scientific articles published by $\mathrm{PhD}$ students with and without Scientific Initiation, but we only selected $\mathrm{PhD}$ students, because their course time is longer, 36 months, according to the current regulation. The activities considered as Scientific Initiation were extracurricular placement, study presentation in scientific events, participation in research or outreach projects, and publication of studies in journals or of abstracts in proceedings of events.

The quantitative data analysis was performed through frequency distribution, and an independent sample t-test was run with $\mathrm{PhD}$ students who carried out some scientific initiation activity and those who did not at a significance level of $5 \%$.

\section{RESULTS}

During the period analysed, 55 graduate students were enrolled in the programme (graph 1). Of these, 63.64 percent $(n=35)$ carried out Scientific Initiation during their undergraduate period and 36.36 percent $(n=20)$ did not engage in any scientific initiation activity.

$\mathrm{PhD}$ students who performed Scientific Initiation $(\mathrm{n}=19)$ achieved a better scientific production, whereas those who did not perform any scientific initiation activity $(n=8)$ had a less expressive scientific production (graph $2 ; \mathrm{p}$-value $=$ 0.047).

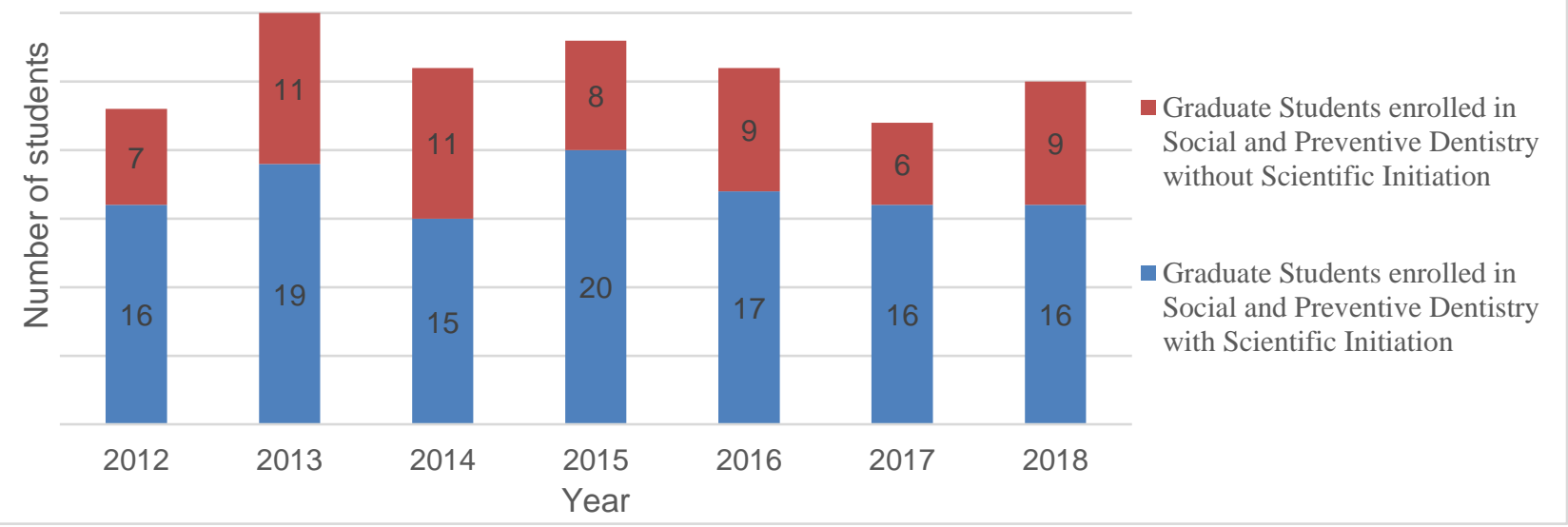

Graph 1. Number of students enrolled in the Public Health Dentistry Graduate Programme per year between 2012 and 2018 


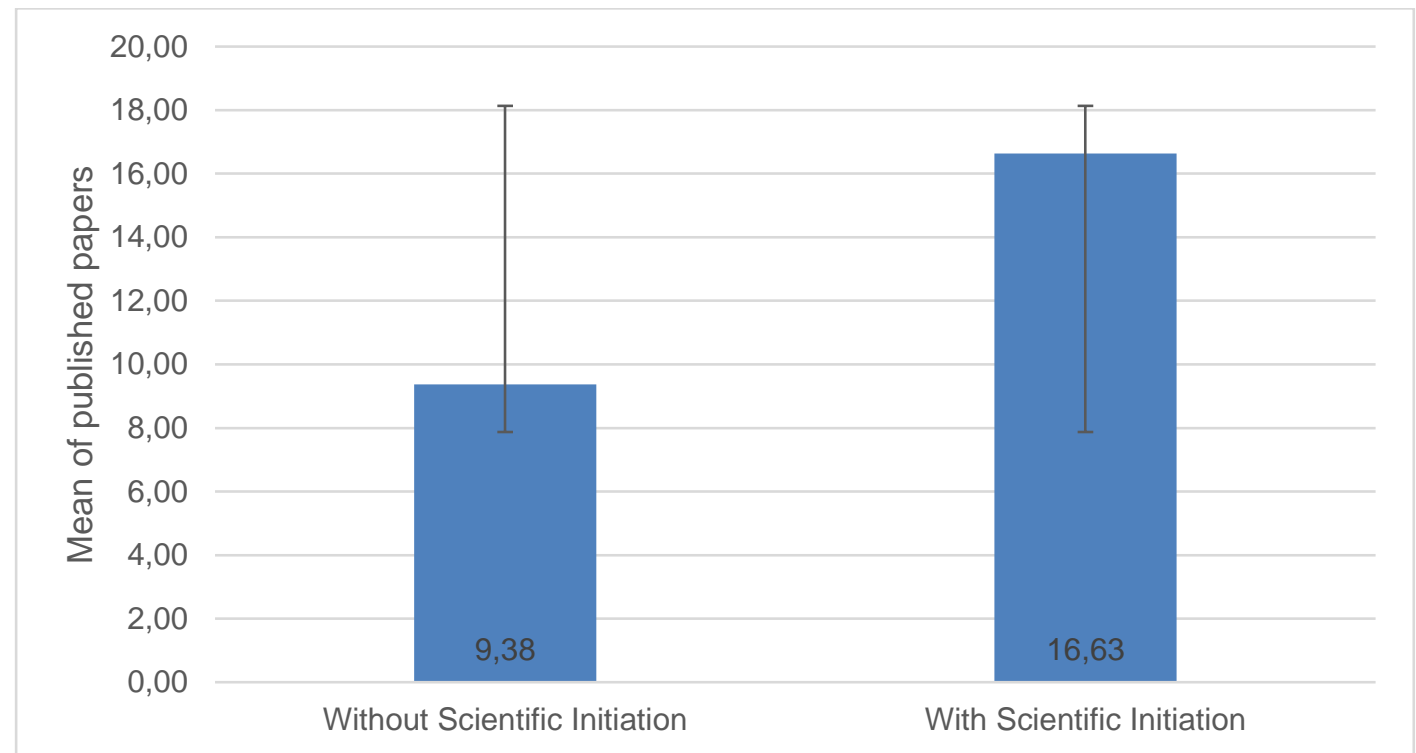

Graph 2: Mean scientific production of graduated students according to their Scientific Initiation activities carried out between 2012 and 2018

\section{DISCUSSION}

Scientific Initiation aims to awaken the scientific vocation of undergraduate students and to encourage potential talents through their participation in a research project under the guidance of a qualified researcher ${ }^{8,13}$. Therefore, students have the opportunity to learn how to carry out research activities by performing literature review, research design, data collection, scientific writing, and presentation of results in scientific publications and events ${ }^{14}$. Scientific Initiation not only encourages undergraduate students to enroll in graduate programmes, but also prepares them to develop their capacity to solve daily problems in the dentistry practice and to critically address adversities faced by the community in which they are inserted ${ }^{8}$.

Governments worldwide have been developing strategies to increase the amount of dental researchers/educators who can train professionals to incorporate new philosophies into their practices ${ }^{15,16}$. It is a shift from a passive learning approach to a critical-thinking learning one $^{17,18}$. North-American dental schools have had to re-structure their curriculum by including new experiences, such as evidence-based dentistry, integration between basic biomedical, behavioral and clinical sciences, establishment of early clinical experiences, and community-based experience learning opportunities. In this case, research and outreach activities provide an essential scenario for students to learn about the real health problems of their community ${ }^{11}$. Historically, there has been a gap between formal learning at universities and these health problems. Since the 2000s, Brazil has initiated a new perspective on the role of teaching-learning and research on dental education. Therefore, Scientific Initiation has been encouraged in higher education institutions and in national and state development agencies as a fostering mechanism to improve the quality of education (learning by research) and to insert undergraduate students in graduate programmes. The present study identified a positive relationship between the performance of Scientific Initiation during undergraduate dentistry courses and insertion in graduate programmes.

An Indian study showed that research 
activities were minimal at the undergraduate level in the country's dentistry programmes; their curricula were so focused on classes and clinics that students hardly had time to conduct research. This study showed that the dental education curriculum should include the process of conducting research to help students to gain logical reasoning skills, which can then be directly applied in clinical dentistry. Thereby, a research component should be the research activity requirement in the undergraduate dental curriculum ${ }^{19}$. Not only India, but also China, underwent a curricular change. There was a concern about professionals being able to independently conduct research and teach in Chinese dental schools ${ }^{20}$, since the development of research and outreach (externships) projects to insert undergraduate students depends on the possibility of training academic leaders with strong research potential ${ }^{19}$.

The scientific initiation activities of this study were developed by inserting undergraduate students in research and outreach (externships) projects with the participation of master's/ $\mathrm{PhD}$ students. As for these activities, undergraduate students were introduced to real learning scenarios, which in turn strengthened their abilities to analyse and assess the community's problems and needs, including creation of solutions for the society and development of critical-thinking skills.

The Brazilian government, through CAPES, has stimulated an increase in the number of articles published in the past years. The number and quality of these articles have been used by CAPES as assessment criteria to qualify all graduate programmes in Brazil. ${ }^{8}$ In the world ranking, Brazil is the second country with the highest number of scientific productions in the dentistry area, and it is the first in South America, according to the SciVal database $^{21}$. Undergraduate students who have carried out scientific initiation activities have participated in this process and become qualified in the writing of scientific articles, which increases the number of published studies as well. The results of this study indicated a positive relationship between the number of articles published and the participation of students in Scientific Initiation activities during undergraduate courses. Students who participated in Scientific Initiation activities had a better average of research production than those who did not. In this case, it should be emphasized that graduate studies in the national scenario not only contribute to the insertion of students in the university as professors, but they also represent attractive professional qualification in the private sector.

This research was developed based on secondary data from Brazilian public agencies, meaning that information on the profile or perception of graduate students included is incomplete. More studies on students' perception are necessary to improve the teaching-learning process in the dental education.

\section{CONCLUSION}

Graduate students with Scientific Initiation achieved a higher number of publications compared to those without Scientific Initiation.

\section{ACKNOWLEDGMENTS}

The authors acknowledge the CAPES for its support.

\section{RESUMO \\ $O$ impacto da Iniciação Científica na produção bibliográfica de pós-graduandos}

A Iniciação Científica tem como objetivo despertar a vocação científica em estudantes de graduação e incentivar potenciais talentos por meio de sua participação em projetos de pesquisa, sob a orientação de um pesquisador qualificado. Este estudo objetivou analisar a produção científica de pós-graduandos com e sem iniciação científica. Trata-se de um estudo transversal, retrospectivo, descritivo, com 
consulta nas plataformas Sucupira do Ministério da Educação e Lattes do Ministério da Ciência, Tecnologia, Inovações e Comunicações no período de 2012 a 2018. No período, foram avaliados o número de alunos de mestrado e doutorado do Programa de Pós-Graduação em Odontologia Preventiva e Social da Universidade Estadual Paulista (Unesp), da Faculdade de Odontologia de Araçatuba. O número de artigos científicos de cada aluno de doutorado com e sem iniciação científica foi analisado. No total, 55 alunos de mestrado e doutorado estavam matriculados no Programa de Pós-Graduação em Odontologia Preventiva e Social, destes $63,64 \%$ $(\mathrm{n}=35)$ realizaram iniciação científica durante a graduação. Observou-se também que os estudantes de doutorado que realizaram iniciação científica $(\mathrm{n}=19)$ obtiveram melhor produção científica $(\mathrm{p}=0,047)$. Concluiu-se que os estudantes de pós-graduação com iniciação científica alcançaram um número de publicações mais significativo em comparação com aqueles sem essa experiência.

Descritores: Educação em Odontologia. Educação de Pós-Graduação em Odontologia. Pesquisa em Odontologia.

\section{REFERENCES}

1. Saliba NA, Moimaz SAS, Garbin CAS, Diniz DG. Dentistry in Brazil: its history and current trends. J Dent Educ. 2009;73(2):225-31.

2. Iacopino AM. The influence of "new science" on dental education: current concepts, trends, and models for the future. J Dent Educ. 2007;71(4):450-62.

3. Cowpe J, Plasschaert A, Harzer W, VinkkaPuhakka H, Walmsley AD. Profile and competences for the graduating European dentist - update 2009. Eur J Dent Educ. 2010;14(4):193-202.

4. Brasil. Conselho Nacional de Educação. Resolução CNE/CES 3, de 19 de fevereiro de 2002. Institui Diretrizes Curriculares Nacionais do Curso de Graduação em Odontologia. [Cited May 10, 2019]. Available from: http://portal.mec.gov.br/cne/arquivos/ pdf/CES032002.pdf

5. Garbin CAS, Saliba NA, Moimaz SAS, Santos KT. The role of universities in the training of health professionals. Rev ABENO. 2006;6(1):6-10.

6. Maltagliati LA, Goldenberg P. Research and curricular reform in dentistry undergraduate courses: origin challenges to current problems. Saúde Soc. 2011;20(2):434-47.

7. Sin MK, Bliquez R. Teaching evidence based practice to undergraduate nursing students. $\mathrm{J}$ Prof Nurs. 2017:33(6):447-51.

8. Brasil. Postgraduate National Plan (PNPG), 2011-2020. Brasília: CAPES; 2010.

9. Morin E. Les sept savoirs nécessaires à l'éducation du futur. Paris: UNESCO; 1999.

10. Erdmann AL, Fernandes JD, Teixeira GA. Overview of nursing education in Brazil: graduation and post graduation. Enferm Foco. 2011;2:89-93.

11. Moimaz SAS, Saliba NA, Zina LG, Saliba O, Garbin CAS. Teaching-learning practices based on real scenarios. Interface. 2010;14(32):69-79.

12. Brasil. Plataforma Lattes. [Cited June 2, 2019]. Available from: http://lattes.cnpq.br/

13. Silva Junior MF, Assis RIF, Sousa HA, Miclos PV, Gomes MJ. Scientific initiation: the perception of academic interest of dentistry of a Brazilian university. Saúde Soc. 2014:23(1):325-35.

14. Cyrillo RJT, Setúbal S, Silva Júnior CT, Velarde LGC, Mattos ACMT, Silva Touça A, et al. Influence of a scientific initiation programme on scientific output of professors on a medical course in Brazil. Rev Port Pneumol. 2008;14(5):635-45.

15. Bertolami $\mathrm{CN}$. The role and importance of research and scholarship in dental education and practice. J Dent Educ. 2002:66(8):918-26. 16. Pinto GS, Nascimento GG, Mendes MS, 
Ogliari FA, Demarco FF, Correa MB. Scholarships for scientific initiation encourage post-graduation degree. Braz Dent J. 2014; 25(1):63-8.

17. Pyle M, Andrieu SC, Chadwick DG, Chmar JE, Cole JR, George MC, et al. The case for change in dental education. J Dent Educ. 2006:70(9):921-4.

18. Elangovan S, Venugopalan SR, Srinivasan S, Karimbux NY, Weistroffer P, Allareddy V. Integration of Basic-Clinical Sciences, PBL, CBL, and IPE in U.S. Dental Schools' Curricula and a proposed integrated curriculum model for the future. J Dent Educ. 2016;80(3):281-90.

19. Elangovan S, Allareddy V, Singh F, Taneja P, Karimbux N. Indian dental education in the new millennium: challenges and opportunities. J Dent Educ. 2010;74(9):1011-6.
20. Sun W, Hu Q, Zhang H, Liu Y, Bensch B, Wang W, et al. A new dental curriculum for chinese research universities. J Dent Educ. 2011;75(10):1374-82.

21. Elsevier. SciVal. [Cited May 10, 2019]. Available from: www.elsevier.com/solutions $\underline{\text { sscival }}$

\section{Correspondence to:}

Dr. Suzely Adas Saliba Moimaz

e-mail: suzely.moimaz@unesp.br

Programa de Pós-Graduação em Odontologia

Preventiva e Preventiva e Social, Núcleo de

Pesquisa em Saúde Coletiva, NEPESCO

Rua José Bonifácio, 1193 Vila Mendonça, 16015-050, Araçatuba/SP Brazil 